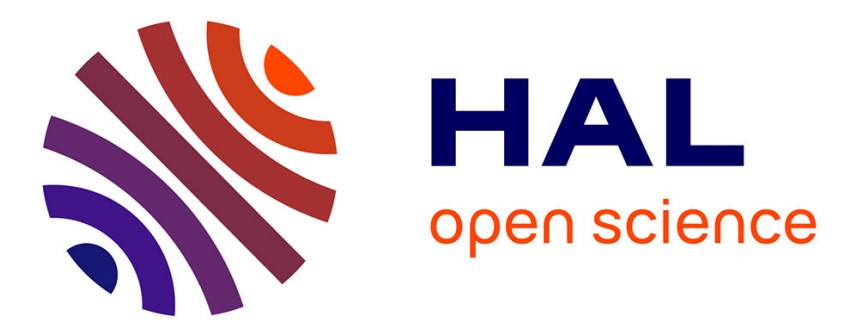

\title{
A solution- and gas-phase study of uranyl hydroxamato complexes
}

Vladimir Sladkov, Mingjian He, Pawel Jewula, Marie-José Penouilh, Stéphane Brandès, Christine Stern, Jean-Claude Chambron, Michel Meyer

\section{- To cite this version:}

Vladimir Sladkov, Mingjian He, Pawel Jewula, Marie-José Penouilh, Stéphane Brandès, et al.. A solution- and gas-phase study of uranyl hydroxamato complexes. Journal of Radioanalytical and Nuclear Chemistry, 2018, 318 (1), pp.259-266. 10.1007/s10967-018-6019-6 . hal-01998942

\section{HAL Id: hal-01998942 \\ https://hal.science/hal-01998942}

Submitted on 21 Dec 2021

HAL is a multi-disciplinary open access archive for the deposit and dissemination of scientific research documents, whether they are published or not. The documents may come from teaching and research institutions in France or abroad, or from public or private research centers.
L'archive ouverte pluridisciplinaire HAL, est destinée au dépôt et à la diffusion de documents scientifiques de niveau recherche, publiés ou non, émanant des établissements d'enseignement et de recherche français ou étrangers, des laboratoires publics ou privés. 


\title{
A Solution and Gas-Phase Study of Uranyl Hydroxamato Complexes
}

\author{
Vladimir Sladkov ${ }^{1 *}$, Mingjian $\mathrm{He}^{1}$, Pawel Jewula ${ }^{2}$, Marie-José Penouilh ${ }^{2}$, Stéphane Brandès ${ }^{2}$, \\ Christine Stern ${ }^{2}$, Jean-Claude Chambron ${ }^{2}$, Michel Meyer ${ }^{2}$ \\ ${ }^{1}$ Institut de Physique Nucléaire d'Orsay (IPNO), UMR 8608, CNRS-IN2P3, Université Paris \\ Sud, 15 rue George Clemenceau, 91406 Orsay Cedex, France \\ ${ }^{2}$ Institut de Chimie Moléculaire de l'Université de Bourgogne (ICMUB), UMR 6302, CNRS, \\ Université Bourgogne-Franche-Comté, 9 avenue Alain Savary, BP 47870, 21078 Dijon \\ Cedex, France
}

\begin{abstract}
This study compares the binding properties towards the uranyl cation of three hydroxamates derived from benzohydroxamic acid (BHAH), $N$-methylacetohydroxamic acid (NMAH) and 1hydroxypiperidine-2-one (PIPOH), as models of the binding sites found in natural chelators that could be involved in the mobilization of uranyl in the vicinity of abandoned mines. Solution speciation studies of the $\mathrm{UO}_{2}{ }^{2+} / \mathrm{BHAH}$ system by affinity capillary electrophoresis allowed to estimate stability constants for both ML $\left(\log K_{110}=7.4(1)\right)$ and $\mathrm{ML}_{2}\left(\log K_{120}=7.0(1)\right)$ species in aqueous media $\left(0.1 \mathrm{M}(\mathrm{H}, \mathrm{Na}) \mathrm{ClO}_{4}, 25{ }^{\circ} \mathrm{C}\right)$, which lie in-between those reported by us elsewhere for $\mathrm{NMA}^{-}$and $\mathrm{PIPO}^{-}$. By contrast, gas phase studies demonstrate that one of the $\mathrm{U}=\mathrm{O}$ bonds can be activated in the $\mathrm{NMA}^{-}$and $\mathrm{PIPO}^{-}$complexes, whereas this is not the case for the $\mathrm{BHA}^{-}$complex.
\end{abstract}

\section{Keywords}

Benzohydroxamic acid, cyclic hydroxamic acid, $\mathrm{U}=\mathrm{O}$ bond activation, speciation, capillary electrophoresis 


\section{Introduction}

Uranium mines have been exploited in France from 1945-2001 [1]. During this period, $5.2 \times$ $10^{7}$ tons of ore have been extracted together with $2 \times 10^{8}$ tons of barren rocks to recover $8 \times$ $10^{4}$ tons of uranium by lixiviation, either in situ (static lixiviation), or in factories (dynamic lixiviation). Barren rocks and residues from static lixiviation have been used for conditioning and warranting the safety of old mining sites. These materials are considered long-lived, weakly or very weakly radioactive $\left(10^{3}-10^{5} \mathrm{~Bq} \mathrm{~kg}^{-1}\right)$. Before pitchblende $\left(\mathrm{UO}_{2}\right)$ deposits were discovered in the Limousin area, the first mines exploited contained ores of the autunite family $\left(\mathrm{M}_{2}\left(\mathrm{UO}_{2}\right)_{2}\left(\mathrm{PO}_{4}\right)_{2}, \mathrm{M}=\mathrm{Ca}, \mathrm{Cu}\right.$, etc. $)$ in which uranium is incorporated in the form of watersoluble uranyl $\left(\mathrm{UO}_{2}{ }^{2+}\right)$ salts. Therefore, understanding the physico-chemical interactions of uranyl with the minerals and biological materials contained in the soils is an important issue [25]. Among the latter, siderophores occupy a prominent position [6-11]. These natural chelators are low molecular weight compounds that are produced and excreted by microorganisms in order to capture $\mathrm{Fe}^{3+}$ from insoluble iron oxo-hydroxides present in the pedological layer [1214]. $\mathrm{Fe}^{3+}$ being hexacoordinate, most siderophores incorporate three bidentate chelating units, which are often derived from hydroxamic acids. The latter coordinate metal cations in the deprotonated, hydroxamate form, as oxygen-based $(O, O)^{-}$anionic chelates. The simple hydroxamic acids NMAH and PIPOH (Fig. 1) have been used as pertinent models of the linear and cyclic hydroxamic acid subunits incorporated into siderophores [15-17]. In addition to these low molecular weight compounds, more complex aquatic humic substances, which derive from the natural transformation of lignin, have been recognized as responsible for the bioavailability of $\mathrm{Fe}^{3+}$ in seawater $[18,19]$. It was proposed that, as siderophores, humic substances could complex $\mathrm{Fe}^{3+}$ thanks to hydroxamate residues [20]. As a matter of fact, simple benzohydroxamic acids were recently used as model compounds for humic substances, able to supply iron to algae [21].

The hypothesis that hydroxamic acid-containing natural compounds could be involved in the complexation of uranyl relies on the similarity of the electronic properties of $\mathrm{Fe}^{3+}$ and $\mathrm{UO}_{2}{ }^{2+}$, which are both Lewis acidic cations [22]. In order to get further insight into this important issue, we compare in this paper the binding properties towards uranyl of a primary hydroxamic acid, namely benzohydroxamic acid (BHAH) taken as a model of aquatic humic substances, with those of $N$-methylacetohydroxamic acid (NMAH) [15,22] and 1-hydroxypiperidine-2-one (PIPOH) [16,17] (Fig. 1), both in the gas phase as well as in aqueous solution. These two 
secondary hydroxamic acids of linear (NAMH) and cyclic (PIPOH) structures can be considered as models for the binding groups incorporated in many siderophores, such as those of the desferrioxamine and exochelin groups, respectively.<smiles>CC(=O)NO</smiles>

$\mathrm{AHAH}$<smiles>CC(=O)N(C)O</smiles>

NMAH<smiles>O=C1CCCCN1O</smiles>

$\mathrm{PIPOH}$<smiles>O=C(NO)c1ccccc1</smiles>

$\mathrm{BHAH}$

Fig. 1 Molecular formulae (cis isomer) and acronym of monohydroxamic acids discussed herein.

\section{Experimental}

The detailed description of the synthesis and characterization of the isolated $\left[\mathrm{UO}_{2}(\mathrm{BHA})_{2}\left(\mathrm{H}_{2} \mathrm{O}\right)\right] \cdot 0.85 \mathrm{H}_{2} \mathrm{O}, \quad\left[\mathrm{UO}_{2}(\mathrm{PIPO})_{2}\left(\mathrm{H}_{2} \mathrm{O}\right)\right]$ and $\left[\mathrm{U}^{18} \mathrm{O}_{2}(\mathrm{PIPO})_{2}\left(\mathrm{H}_{2} \mathrm{O}\right)\right]$ complexes together with the instrumental methods employed (FT-MIR, Raman, and UV-vis diffuse reflectance spectrophotometry; TGA; (+)-HR-ESI-MS; affinity capillary electrophoresis) is available as Supplementary Information. All errors reported under parentheses correspond to the standard deviation $(1 \sigma)$ rounded to one significant digit.

\section{Results and discussion}

\section{Synthesis and characterization of the bischelated uranyl complexes}

Treatment of a slight excess (2.5-3 equiv.) of hydroxamic acid dissolved in water with $\left[\mathrm{UO}_{2}\left(\mathrm{NO}_{3}\right)_{2}\left(\mathrm{H}_{2} \mathrm{O}\right)_{2}\right] \cdot 4 \mathrm{H}_{2} \mathrm{O}$ immediately affords an orange solution, suggesting the formation of complexes that concomitantly lowers the $\mathrm{pH}$ to about 2.2. Upon neutralization with an aqueous base solution ( $\sim 0.1 \mathrm{M} \mathrm{N}\left(\mathrm{CH}_{3}\right)_{4} \mathrm{OH}$ or $\left.\mathrm{KOH}\right)$, a red-orange precipitate corresponding to the neutral bischelated complexes $\left[\mathrm{UO}_{2}(\mathrm{~L})_{2}\left(\mathrm{H}_{2} \mathrm{O}\right)\right] \cdot x \mathrm{H}_{2} \mathrm{O}\left(x=1\right.$ for $\mathrm{L}=\mathrm{BHA}^{-}, x=0$ for $\mathrm{L}=\mathrm{PIPO}^{-}$ ) could be isolated in good yield (60-90\%). Both synthesized compounds gave satisfactory elemental analysis and were further characterized by TGA (Fig. S1-S2), IR, Raman, and UVvis diffuse reflectance spectroscopy in the solid state, and by HR-ESI-MS spectroscopy in solution. Details can be found in the experimental section included in the Supplementary Information. 
Vibrational spectroscopy (MIR and Raman) provides a convenient mean to probe the chemical environment of the uranyl cation in its equatorial plane $[23,15,17]$. Indeed, both the symmetric $\left(v_{\mathrm{s}}\right)$ and antisymmetric $\left(v_{\mathrm{as}}\right) \mathrm{U}=\mathrm{O}$ stretching modes, respectively Raman and IR active, are significantly red-shifted upon chelation with hydroxamate ligands with respect to crystalline $\left[\mathrm{UO}_{2}\left(\mathrm{NO}_{3}\right)_{2}\left(\mathrm{H}_{2} \mathrm{O}\right)_{2}\right] \cdot 4 \mathrm{H}_{2} \mathrm{O}\left(v_{\mathrm{s}}=869 \mathrm{~cm}^{-1}\right.$ and $\left.v_{\mathrm{as}}=941 \mathrm{~cm}^{-1}\right)$. Both complexes give rise to strong IR absorptions at $906 \mathrm{~cm}^{-1}$, while the Raman shift occurs at $830 \mathrm{~cm}^{-1}$ for $\left[\mathrm{UO}_{2}(\mathrm{BHA})_{2}\left(\mathrm{H}_{2} \mathrm{O}\right)\right] \cdot 0.85 \mathrm{H}_{2} \mathrm{O}$ and $835 \mathrm{~cm}^{-1}$ in the case of $\left[\mathrm{UO}_{2}(\mathrm{PIPO})_{2}\left(\mathrm{H}_{2} \mathrm{O}\right)\right]$, as typically observed for dihydroxamato uranyl complexes [15,24-26]. A broad feature around $3200 \mathrm{~cm}^{-1}$ also attests to the presence of water.

Diffuse reflectance spectra of genuine powdered samples show in the UV range a broad feature corresponding likely to ligand-centered $\pi \rightarrow \pi^{*}$ transitions at $252 \mathrm{~nm}$ in the case of $\left[\mathrm{UO}_{2}(\mathrm{PIPO})_{2}\left(\mathrm{H}_{2} \mathrm{O}\right)\right]$ or at $274 \mathrm{~nm}$ in the case of $\left[\mathrm{UO}_{2}(\mathrm{BHA})_{2}\left(\mathrm{H}_{2} \mathrm{O}\right)\right] \cdot 0.85 \mathrm{H}_{2} \mathrm{O}$. In the visible range, two broad and unstructured bands can be assigned to LMCT transitions from the filled $\pi$ to the empty uranium-centered $5 f$ orbitals [26]. Microcrystalline $\left[\mathrm{UO}_{2}(\mathrm{PIPO})_{2}\left(\mathrm{H}_{2} \mathrm{O}\right)\right]$ gives rise to two well-defined maxima at 386 and $501 \mathrm{~nm}$, while both bands of $\left[\mathrm{UO}_{2}(\mathrm{BHA})_{2}\left(\mathrm{H}_{2} \mathrm{O}\right)\right] \cdot 0.85 \mathrm{H}_{2} \mathrm{O}$ overlap to such an extent that only shoulders are visible around 350 and $470 \mathrm{~nm}$. These characteristics are close to those reported for the red-colored $\left\{\left[\mathrm{UO}_{2}(\mathrm{FHA})_{2}\right]\right\}_{n}$ coordination polymer formed with formohydroxamate $\left(\lambda_{\max }=370(\mathrm{sh})\right.$ and $475 \mathrm{~nm})$ [26]. Noteworthy, both LMCT band maxima of $\left[\mathrm{UO}_{2}(\mathrm{PIPO})_{2}\left(\mathrm{H}_{2} \mathrm{O}\right)\right]$ undergo hypsochromic shifts upon dissolution of the complex in methanol $\left(\lambda_{\max }=369\right.$ and $\left.474 \mathrm{~nm}\right)$, whereas slight bathochromic shifts are observed for a methanolic solution of $\left[\mathrm{UO}_{2}(\mathrm{BHA})_{2}\left(\mathrm{H}_{2} \mathrm{O}\right)\right] \cdot 0.85 \mathrm{H}_{2} \mathrm{O}\left(\lambda_{\max } \approx 360\right.$ and $\left.\approx 460 \mathrm{~nm}\right)$. It can therefore be concluded that some structural rearrangements and/or partial dissociation of the complexes occur in solution. In the crystal state, we have recently shown that $\left[\mathrm{UO}_{2}(\mathrm{PIPO})_{2}\left(\mathrm{H}_{2} \mathrm{O}\right)\right]$ molecules assemble into a head-to-head chain oriented along the $x$ direction through hydrogen bonds involving the protons of the bound water molecule and both hydroxamic $\mathrm{O}_{\mathrm{N}}$ atoms from the adjacent motif [17]. Disruption of these H-bonds by methanol might likely affect the coordination sphere around $\mathrm{UO}_{2}{ }^{2+}$ and thus the electronic properties. Although no X-ray quality crystals of $\left[\mathrm{UO}_{2}(\mathrm{BHA})_{2}\left(\mathrm{H}_{2} \mathrm{O}\right)\right]$ could be grown, it can be reasonably assumed that the isolated material has also a polymeric structure, like other uranyl complexes incorporating the primary formo- [26], aceto- [27], or salicylhydroxamate chelates [28]. This assumption is further supported by the very low solubility in water and methanol. If so, slight modifications of the uranyl chromophore 
can be expected upon solubilizing the solid material, which should be reflected by shifts of the charge-transfer bands.

\section{Gas phase properties of the bischelated uranyl complexes}

Only sparingly soluble in pure methanol, the neutral $\left[\mathrm{UO}_{2}(\mathrm{BHA})_{2}\left(\mathrm{H}_{2} \mathrm{O}\right)\right] \cdot 0.85 \mathrm{H}_{2} \mathrm{O}$ complex readily dissolved upon addition of $15 \% \mathrm{v} / \mathrm{v}$ of DMSO. Thus, a $0.5 \mathrm{mM}$ methanolic solution containing $0.2 \mathrm{mM}$ of DMSO was analyzed by (+)-HR-ESI-MS (Fig. S3). Simulation of the isotopic patterns allowed us to assign without ambiguity all major manifolds appearing in the spectrum. Electrospray ionization generates a variety of solvated monochelated species at $\mathrm{m} / \mathrm{z}$ $=484.095 \quad\left[\mathrm{UO}_{2}(\mathrm{BHA})(\mathrm{DMSO})\right]^{+}, \quad 502.105 \quad\left[\mathrm{UO}_{2}(\mathrm{BHA})(\mathrm{DMSO})\left(\mathrm{H}_{2} \mathrm{O}\right)\right]^{+}, \quad 516.121$ $\left[\mathrm{UO}_{2}(\mathrm{BHA})(\mathrm{DMSO})\left(\mathrm{CH}_{3} \mathrm{OH}\right)\right]^{+}, \quad 562.109 \quad\left[\mathrm{UO}_{2}(\mathrm{BHA})(\mathrm{DMSO})_{2}\right]^{+}$, in addition to the bischelated sodium adduct $\left[\mathrm{UO}_{2}(\mathrm{BHA})_{2}(\mathrm{DMSO})+\mathrm{Na}\right]^{+}$at $\mathrm{m} / z=643.124$, supporting the identity of the isolated complex. MS/MS collision induced dissociation (CID) experiments performed on all of the aforementioned mass-selected cations showed the progressive loss of the various solvent molecules with increasing collision energy (Fig. S4).

These results are in marked contrast with the gas-phase behavior of $\left[\mathrm{UO}_{2}(\mathrm{PIPO})_{2}\left(\mathrm{H}_{2} \mathrm{O}\right)\right]$. Indeed, the MS spectrum of a pure methanolic solution of this compound shows the formation of different monocationic complexes of general $\left[\mathrm{UO}_{2}(\mathrm{PIPO})(\mathrm{L})_{n}\right]^{+}$formula, with $\mathrm{L}=\mathrm{PIPOH}$, $\mathrm{H}_{2} \mathrm{O}$, or $\mathrm{CH}_{3} \mathrm{OH}$, in addition to some sodium adducts (see the experimental section in the SI). To get further insight, some mass-selected cations were subjected to CID experiments. MS/MS fragmentation of $\left[\mathrm{UO}_{2}(\mathrm{PIPO})(\mathrm{PIPOH})\right]^{+}(\mathrm{m} / \mathrm{z}=499.161)$ affords the $\left[\mathrm{UO}_{2}(\mathrm{PIPO})\right]^{+}$cation $(\mathrm{m} / \mathrm{z}$ $=384.098)$ together with its water adduct $(\mathrm{m} / z=402.104) . \mathrm{CID}$ of the $\left[\mathrm{UO}_{2}(\mathrm{PIPO})(\mathrm{PIPOH})_{2}\right]^{+}$ cation $(m / z=614.225)$ gives rise to a new signal at $m / z=499.156$ associated to the loss of an intact molecule of bound PIPOH ligand (Fig. S5). The thereby generated $\left[\mathrm{UO}_{2}(\mathrm{PIPO})(\mathrm{PIPOH})\right]^{+}$cation can further react in the collision chamber with a molecule of water, producing the $\left[\mathrm{UO}_{2}(\mathrm{PIPO})(\mathrm{PIPOH})\left(\mathrm{H}_{2} \mathrm{O}\right)\right]^{+}$ion detected at $\mathrm{m} / \mathrm{z}=517.167$. More intriguingly, $\mathrm{CID}$ of $\left[\mathrm{UO}_{2}(\mathrm{PIPO})(\mathrm{PIPOH})_{2}\right]^{+}$generates another peak at $\mathrm{m} / \mathrm{z}=596.209$. Accordingly, the lost fragment has a mass of 18.016 a.m.u., suggesting the release of a molecule of water albeit the parent cation is not hydrated. Hence, the abstracted oxygen atom found in the eliminated water molecule can originate either from one hydroxamic ligand or from the $\mathrm{UO}_{2}{ }^{2+}$ cation upon $\mathrm{U}=\mathrm{O}$ bond cleavage. In order to check the latter possibility and to discard the former, we prepared and analyzed likewise the ${ }^{18} \mathrm{O}$-labelled complex $\left[\mathrm{U}^{18} \mathrm{O}_{2}(\mathrm{PIPO})_{2}\left(\mathrm{H}_{2} \mathrm{O}\right)\right]$ 
obtained by reacting $\mathrm{U}^{18} \mathrm{O}_{2}{ }^{2+}$ with PIPOH (Fig. S6). As expected, the signal assigned to $\left[\mathrm{U}^{18} \mathrm{O}_{2}(\mathrm{PIPO})(\mathrm{PIPOH})_{2}\right]^{+}$was shifted by 4 mass units with respect to the unlabeled complex $(m / z=618.227)$, while CID unambiguously revealed the elimination of a fragment of 20.014 a.m.u. corresponding to $\mathrm{H}_{2}{ }^{18} \mathrm{O}$. This observation clearly ascertains that one "yl" oxygen atom from the $\mathrm{UO}_{2}{ }^{2+}$ core was abstracted, suggesting that one $\mathrm{U}=\mathrm{O}$ bond is broken during the collision process. This experiment definitively rules out the second conceivable waterelimination mechanism, whereby the oxygen atom would have originated from one coordinated ligand upon $\mathrm{N}-\mathrm{O}$ or $\mathrm{C}-\mathrm{O}$ bond cleavage.

Thus far, CID induced $\mathrm{U}=\mathrm{O}$ bond activation has only rarely been reported in the literature [2932], although Terencio et al. described very recently a similar situation for the related $\left[\mathrm{UO}_{2}(\mathrm{NMA})(\mathrm{NMAH})_{2}\right]^{+}$gas-phase complex [22]. Probed by infrared multiphoton dissociation spectroscopy (IRMPD) and DFT calculations, the most stable and thus plausible structure of that cation revealed the presence of only four oxygen atoms in the equatorial plane of the bound uranium center, two of them being provided by a bischelated $\mathrm{NMA}^{-}$ligand, while the two remaining ones are provided by carbonyl groups of the monodentate NMAH moieties. One N$\mathrm{OH}$ function was found interacting with one "yl" oxygen atom and the second hydroxyl group was also hydrogen bonded to the former $\mathrm{N}-\mathrm{OH}$ oxygen atom. Evidence for $\mathrm{U}=\mathrm{O}$ bond activation was clearly provided by the disappearance of the characteristic antisymmetric $\mathrm{O}=\mathrm{U}=\mathrm{O}$ stretching mode at $\sim 940 \mathrm{~cm}^{-1}$ in the IRMPD spectrum of the dehydrated species, which therefore incorporates an $\mathrm{UO}^{4+}$ core. Water elimination appeared to be favored by the direct apical $\mathrm{U}=\mathrm{O} \cdots \mathrm{HO}-\mathrm{N}$ hydrogen bond that weakens the $\mathrm{U}=\mathrm{O}$ bond and by the nearby location of a second hydroxyl proton [32,33]. Interestingly, neither the dehydrated $\left[\mathrm{UO}(\mathrm{NMA})_{3}\right]^{+}$nor $\left[\mathrm{UO}(\mathrm{PIPO})_{3}\right]^{+}$cation underwent further dissociation or bond activation upon increasing the collision energy. The reason why $\left[\mathrm{UO}_{2}(\mathrm{BHA})_{2}\left(\mathrm{H}_{2} \mathrm{O}\right)\right]$ behaves markedly differently from $\left[\mathrm{UO}_{2}(\mathrm{PIPO})_{2}\left(\mathrm{H}_{2} \mathrm{O}\right)\right]$ or $\left[\mathrm{UO}_{2}(\mathrm{NMA})_{2}\left(\mathrm{H}_{2} \mathrm{O}\right)\right]$ in an ESI source is not fully clear at that point.

\section{Affinity capillary electrophoresis (ACE)}

Uranyl complex formation equilibria with benzohydroxamic acid have been investigated at constant ionic strength $\left(I=0.1 \mathrm{M}(\mathrm{H}, \mathrm{Na}) \mathrm{ClO}_{4}\right), \mathrm{pH}(2.00(5)$ and $2.50(5))$, and temperature $(T$ $=298(1) \mathrm{K}$ ) by affinity capillary electrophoresis (ACE) in aqueous media. This speciation technique relies on the changes of the electrophoretic mobility of the detected species that is produced by the interaction with substrates present in the background electrolytes (BGE) [34- 
37]. Recently, ACE has been successfully used for measuring uranyl binding constants with both organic and inorganic ligands in aqueous solution [38-40,17,41]. Global stability constants $\beta_{m l h}$ associated to equilibrium (1) are defined as molar concentration ratios according to Eq. (2), in which $\mathrm{L}^{-}$stands for the deprotonated ligand, while charges are omitted for sake of clarity.

$$
\begin{gathered}
m \mathrm{UO}_{2}^{2+}+l \mathrm{~L}^{-}+h \mathrm{H}^{+} \leftrightarrows\left[\left(\mathrm{UO}_{2}\right)_{m}(\mathrm{~L})_{l} \mathrm{H}_{h}\right]^{(2 m+h-l)+} \\
\beta_{m l h}=\frac{\left[\left(\mathrm{UO}_{2}\right)_{m}(\mathrm{~L})_{l} \mathrm{H}_{h}\right]}{\left[\mathrm{UO}_{2}\right]^{m}[\mathrm{~L}]^{l}[\mathrm{H}]^{h}}
\end{gathered}
$$

A UV detector was used to monitor the migration of the uranium(VI) species as a function of the total BHAH concentration present in the BGE. Fig. S7 reproduces experimental electrophoregrams recorded for a total uranyl concentration of $0.1 \mathrm{mM}$ at both considered $\mathrm{pH}$ values. Each trace shows a single signal for which the characteristic migration time taken at the peak maximum $(t)$ increases with the total BHAH content. Such a behavior is typically observed for labile systems and reflects fast ligand exchange processes at the separation time scale ( 4 $\min )$ between the free and bound uranyl species $[35,42,43]$. At $\mathrm{pH} 2.50$, uranyl migration is slowed down much more than at $\mathrm{pH} 2.00$ for an identical total ligand concentration, suggesting complex formation to a greater extend. Chelation under strongly acidic conditions was further supported by a bathochromic shift of the absorption band, as the free uranyl peak detected at $200 \mathrm{~nm}$ progressively vanishes. Hence, the monitoring wavelength, initially set at $200 \mathrm{~nm}$ $\left([\mathrm{BHAH}]_{\mathrm{tot}}=0-2 \mathrm{mM}\right)$, was changed first to $230 \mathrm{~nm}\left([\mathrm{BHAH}]_{\mathrm{tot}}=5-20 \mathrm{mM}\right)$, and finally to $250 \mathrm{~nm}$ for the last run $\left([\mathrm{BHAH}]_{\mathrm{tot}}=50 \mathrm{mM}\right)$.

The observed electrophoretic mobility ( $\mu_{\mathrm{obs}}$ ) for labile systems is related to the experimental migration time ( $t$ ) by Eq. (3), in which $L_{\mathrm{t}}$ stands for the total capillary length $(\mathrm{m}), L_{\mathrm{d}}$ for the distance between the capillary inlet and the detection window $(\mathrm{m}), U$ for the applied voltage $(\mathrm{V})$, and $t_{\text {eof }}$ for the migration time of the neutral marker (s). Noteworthy, $t_{\text {eof }}(9 \min 23 \mathrm{~s})$ remained constant within \pm 8 s over the entire concentration range, excluding any complications associated with viscosity effects $[40,44]$. 


$$
\mu_{\mathrm{obs}}=\frac{L_{\mathrm{t}} L_{\mathrm{d}}}{U}\left(\frac{1}{t}-\frac{1}{t_{\mathrm{eof}}}\right)
$$

Variations of $\mu_{\mathrm{obs}}$ with the total amount of ligand introduced in the BGE (Fig. 2) can be modelled by expression (4), in which $\alpha_{m l h}$ corresponds to the molar fraction of any uranylcontaining species and $\mu_{m l h}$ to the intrinsic electrophoretic mobility of the pure $\left[\left(\mathrm{UO}_{2}\right)_{m}(\mathrm{~L})_{l} \mathrm{H}_{h}\right]^{(2 m+h-l)+}$ complex. It should be noted that neutral complexes, e.g. $\left[\mathrm{UO}_{2}(\mathrm{BHA})_{2}\left(\mathrm{H}_{2} \mathrm{O}\right)\right]$, do not contribute directly to the overall electrophoretic mobility $\left(\mu_{m l h}=0\right.$ $\mathrm{m}^{2} \mathrm{~V}^{-1} \mathrm{~s}^{-1}$ ), but only indirectly as their occurrence impacts the molar fractions of the other charged species.

$$
\mu_{\mathrm{obs}}=\sum \alpha_{m l h} \mu_{m l h}
$$

Under our acidic conditions, uranium(VI) prevails in the form of the pentaaquo uranyl dication. According to the overall equilibrium (1), progressive chelation of $\left[\mathrm{UO}_{2}\left(\mathrm{H}_{2} \mathrm{O}\right)_{5}\right]^{2+}$ by the hydroxamate anionic ligand lowers the overall charge and simultaneously increases the hydrodynamic radius. Both effects are responsible for reducing the apparent electrophoretic mobility (Fig. 2), as reflected by longer migration times. Nonlinear least-squares fit (NLLS) of the experimental $\mu_{\mathrm{obs}}$ values obtained at different total ligand concentrations, was performed for three chemical models including the formation of either the sole monochelate $\left[\mathrm{UO}_{2}(\mathrm{BHA})\left(\mathrm{H}_{2} \mathrm{O}\right)_{3}\right]^{+}\left(\beta_{110}\right.$, model 1:1), the sole neutral bischelate $\left[\mathrm{UO}_{2}(\mathrm{BHA})_{2}\left(\mathrm{H}_{2} \mathrm{O}\right)\right]\left(\beta_{120}\right.$, model 1:2), or both complexes ( $\beta_{110}$ and $\beta_{120}$, model 1:1 \& 1:2). 


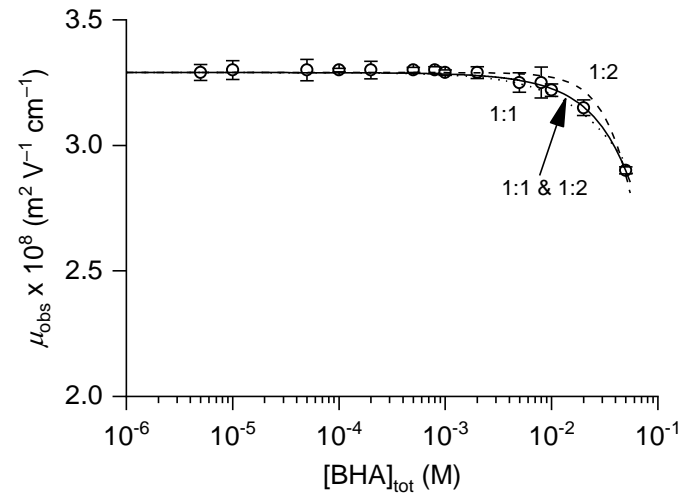

(a)

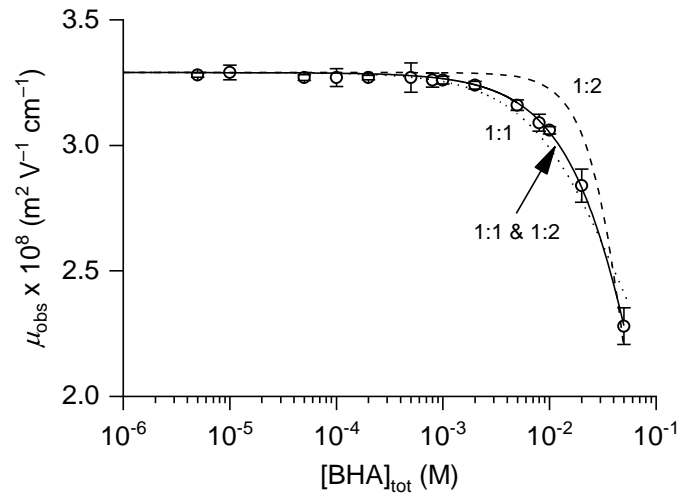

(b)

Fig. 2 Variations of the observed electrophoretic mobility of uranyl as a function of the total BHAH concentration at $\mathrm{pH}=2.00(5)$ (a) and 2.50(5) (b). $I=0.1 \mathrm{M}(\mathrm{H}, \mathrm{Na}) \mathrm{ClO}_{4}, T=298(1)$ $\mathrm{K},[\mathrm{U}(\mathrm{VI})]_{\mathrm{tot}}=0.1 \mathrm{mM}$. The solid lines correspond to the best fit obtained for the model $1: 1 \&$ $1: 2$ with $\mu_{110}=1.4 \times 10^{-8} \mathrm{~m}^{2} \mathrm{~V}^{-1} \mathrm{~s}^{-1}$ taken as fixed value. The calculated curves for the $1: 1$ and 1:2 models are drawn as doted and dashed lines, respectively. Error bars correspond to the confidence interval at the $95 \%$ probability level of the average mobility calculated for three replicates $( \pm t \sigma / \sqrt{n})$.

Since Eq. (4) is homogeneous to the expression of the NMR chemical shift for a given spin system present in several species in fast exchange, ACE data can be advantageously processed with the HypNMR program [45]. This software solves the mass-balance equations for all data points at each NLLS cycle and thus allows refining both the equilibrium constants and the intrinsic electrophoretic mobilities $\left(\mu_{m l h}\right)$. Because $\left[\mathrm{UO}_{2}(\mathrm{BHA})_{2}\left(\mathrm{H}_{2} \mathrm{O}\right)\right]$ is a neutral species, $\mu_{120}$ was set at zero. Likewise, the protonation constant of $\mathrm{BHA}^{-}$was fixed to the value taken from the literature at the same temperature and ionic strength $\left(\log K_{011}=8.80\right.$; selected data are collected in Table S1). Nevertheless, the refinement failed to converge when the $\beta_{110}$ and $\mu_{110}$ were allowed to vary simultaneously, as a consequence of the rather flat error hypersurface in the $\mu_{110}$ direction. In other words, the system suffers from a mathematical indetermination, meaning that the product $\alpha_{110} \mu_{110}$ is well defined but each individual term cannot be precisely determined. This behavior is a direct consequence of the non-sigmoidal shape of both curves shown in Fig. 2, suggesting that the complex formation is far from being complete. To reach convergence, it was therefore necessary to make a reasonable guess of the $\mu_{110}$ value and keep it constant. As a first approximation, the mobility of $\left[\mathrm{UO}_{2}(\mathrm{BHA})\left(\mathrm{H}_{2} \mathrm{O}\right)_{3}\right]^{+}$was assumed to be close to the experimental value determined for the related complex $\left[\mathrm{UO}_{2}(\mathrm{PIPO})\left(\mathrm{H}_{2} \mathrm{O}\right)_{3}\right]^{+}\left(\mu_{110}\right.$ $\left.=1.44(6) \times 10^{-8} \mathrm{~m}^{2} \mathrm{~V}^{-1} \mathrm{~s}^{-1}\right)$ [17], implicitly suggesting that the Stokes radii of both monovalent cations are similar. Considering the hydrophobicity of the phenyl substituent attached to the carbonyl group of BHAH and its larger size when compared to the cyclohexyl ring of PIPOH, it might be anticipated that the radius of $\left[\mathrm{UO}_{2}(\mathrm{BHA})\left(\mathrm{H}_{2} \mathrm{O}\right)_{3}\right]^{+}$is somewhat larger than that of 
the model complex $\left[\mathrm{UO}_{2}(\mathrm{PIPO})\left(\mathrm{H}_{2} \mathrm{O}\right)_{3}\right]^{+}$, and consequently $\mu_{110}$ should be slightly lower. We therefore set $\mu_{110}$ at $1.4 \times 10^{-8} \mathrm{~m}^{2} \mathrm{~V}^{-1} \mathrm{~s}^{-1}$, which can be considered as an upper limit. In turn, the well-defined plateau seen in Fig. 2 at low total BHAH concentrations enabled us to calculate a reliable estimate for the mobility of free uranyl. The best-fit value $\left(\mu_{100}=3.295(3) \times 10^{-8} \mathrm{~m}^{2}\right.$ $\mathrm{V}^{-1} \mathrm{~s}^{-1}$ ) found for model 1:1 \& 1:2 (vide infra) is in excellent accordance with the mean value determined in the absence of ligand at both pH's $\left(\mu_{100}=3.287(8) \times 10^{-8} \mathrm{~m}^{2} \mathrm{~V}^{-1} \mathrm{~s}^{-1}\right)$.

Under such conditions, model 1:2 gave the poorest fit at any $\mathrm{pH}$ value and had to be discarded, while model 1:1 did not reproduce well all the data points, especially those measured at $\mathrm{pH} 2.50$ for the highest ligand concentrations. The goodness-of-fit, assessed by the overall standard deviation returned by the software and by the visual inspection of the residues, significantly improved when the three species model 1:1 \& 1:2 was considered. Best estimates of the overall stability constants defined by Eq. (2) were obtained after merging all data points recorded at $\mathrm{pH} 2.00$ and 2.50. Refined values are $\log \beta_{110}=7.43(2)$ and $\log \beta_{120}=14.47(4)$. Accordingly, the stepwise stability constant of $\left[\mathrm{UO}_{2}(\mathrm{BHA})_{2}\left(\mathrm{H}_{2} \mathrm{O}\right)\right]$, expressed as $\log K_{120}=\log \beta_{120}-$ $\log \beta_{110}$, equals 7.04(6).

Since the mobility of $\left[\mathrm{UO}_{2}(\mathrm{BHA})\left(\mathrm{H}_{2} \mathrm{O}\right)_{3}\right]^{+}$is not known precisely, a sensitivity study was performed by assuming an uncertainty on $\mu_{110}$ of ca. $25 \%$ or $\pm 0.4 \times 10^{-8} \mathrm{~m}^{2} \mathrm{~V}^{-1} \mathrm{~s}^{-1}$ [46]. When $\mu_{110}$ was set at the lower boundary value of $1.0 \times 10^{-8} \mathrm{~m}^{2} \mathrm{~V}^{-1} \mathrm{~s}^{-1}$, the returned equilibrium constants were lowered by 0.08 and $0.15 \log$ units, respectively, as the refinement converged for $\log \beta_{110}=7.35(2)$ and $\log \beta_{120}=14.32(6)$, while the overall standard deviation of the fit increased by ca. $4.5 \%$. For $\mu_{110}=1.8 \times 10^{-8} \mathrm{~m}^{2} \mathrm{~V}^{-1} \mathrm{~s}^{-1}$, a less likely situation as stressed above, the program returned higher $\beta_{10}$ values $\left(\log \beta_{110}=7.53(2), \log \beta_{120}=14.62(3)\right)$. As a matter of fact, the confidence interval on both stepwise binding constants has to be enlarged by about \pm $0.1 \log$ unit and the proposed values are $\log K_{110}=7.4(1)$ and $\log K_{120}=7.0(1)$. Accordingly, the molar fraction of $\left[\mathrm{UO}_{2}(\mathrm{BHA})\left(\mathrm{H}_{2} \mathrm{O}\right)_{3}\right]^{+}$reaches 17 and $36 \%$ at $\mathrm{pH} 2.00$ and 2.50, respectively, at the highest total ligand concentration used herein $(50 \mathrm{mM})$. In turn, only $10 \%$ of the total uranium occurs as the neutral bischelated complex at $\mathrm{pH} 2.50$, which is within the threshold range for defining a minor species. At pH 2.00, $\alpha_{120}$ is less than $2 \%$, in agreement with the experimental finding that $\left[\mathrm{UO}_{2}(\mathrm{BHA})_{2}\left(\mathrm{H}_{2} \mathrm{O}\right)\right]$ does not contribute to the overall electrophoretic mobility. Based on that, the $\log K_{120}$ value should be considered as less reliable than $\log K_{110}$, and its uncertainty range is probably larger than \pm 0.1 . 
Table 1 Literature survey of the stability constants for the uranyl/benzohydroxamate $\left(\mathrm{BHA}^{-}\right)$ system

\begin{tabular}{|c|c|c|c|c|c|c|}
\hline $\log K_{110}$ & $\log K_{120}$ & $I(\mathrm{M})$ & Medium & $T(\mathrm{~K})$ & Method $^{a}$ & Ref \\
\hline $7.51(5)$ & $7.1(1)$ & $\rightarrow 0^{b}$ & $\mathrm{NaClO}_{4}$ & 295.2 & UV-vis & [47] \\
\hline $7.5(1)$ & $8.7(5)$ & $\rightarrow 0^{b}$ & $\mathrm{NaClO}_{4}$ & 298.2 & TRLFS & {$[48]$} \\
\hline $7.8(2)$ & $7.2(2)$ & $\rightarrow 0^{b}$ & $(\mathrm{H}, \mathrm{Na}) \mathrm{ClO}_{4}$ & $298(1)$ & ACE & This work \\
\hline 8.72 & 8.05 & Variable & $\mathrm{KClO}_{4}$ & 298.2 & Pot. & [49] \\
\hline $7.96(5)$ & $7.3(1)$ & 0.1 & $\mathrm{NaClO}_{4}$ & 295.2 & UV-vis & [47] \\
\hline 7.9(1) & $9.0(5)$ & 0.1 & $\mathrm{NaClO}_{4}$ & 298.2 & TRLFS & {$[48]$} \\
\hline $7.4(1)$ & $7.0(1)$ & 0.1 & $(\mathrm{H}, \mathrm{Na}) \mathrm{ClO}_{4}$ & $298(1)$ & ACE & This work \\
\hline 9.03 & 8.91 & 0.1 & $\mathrm{NaClO}_{4}$ & 303.2 & Pot. & {$[50]$} \\
\hline $7.42(1)$ & $6.77(1)$ & 0.1 & $\mathrm{NaNO}_{3}$ & 298.2 & Pot. & {$[51]$} \\
\hline $7.42(3)$ & $6.70(1)$ & 0.1 & $\mathrm{NaNO}_{3}$ & 298.2 & Pot. & {$[52]$} \\
\hline $7.49(3)$ & $6.68(8)$ & 0.1 & $\mathrm{KNO}_{3}$ & 298.2 & Pot. & {$[53]$} \\
\hline 7.7 & & 1.0 & $\mathrm{NaClO}_{4}$ & 293.2 & UV-vis & {$[54]$} \\
\hline
\end{tabular}

${ }^{a}$ Method used: absorption spectrophotometry (UV-vis), affinity capillary electrophoresis (ACE), glasselectrode potentiometry (Pot.), time-resolved laser-induced fluorescence spectroscopy (TRLFS). ${ }^{b}$ Extrapolation to $I=0$ using the Davies equation (Eq. (5)).

Values of the stepwise equilibrium constants $\left(K_{m l h}\right)$ determined in this work for the $\mathrm{UO}_{2}{ }^{2+} / \mathrm{BHA}^{-}$system are compared in Table 1 to those reported in the literature. Most data were determined by glass-electrode potentiometry, although some authors used UV-vis absorption spectrophotometry or time-resolved laser fluorescence spectroscopy (TRLFS), but ACE has never been applied until now. Examination of Table 1 reveals three potentiometric studies carried out in nitrate media at the same temperature $(298.2 \mathrm{~K})$ and ionic strength $(I=0.1 \mathrm{M})$ as our work, which propose remarkably consistent values for $\log K_{110}$ and $\log K_{120}$, averaging 7.44(4) and 6.72(5), respectively [51-53]. Noteworthy, the $\log K_{110}$ value determined herein by $\mathrm{ACE}$ is in excellent accordance with those of references [51-53], while our log $K_{120}$ is slightly higher by ca. 0.3 units.

In contrast, the equilibrium constants determined at $303.2 \mathrm{~K}$ by Dutt and Seshari [50] appear as outliers, as they exceed by more than 1.5 orders of magnitude the latter data. It can also be noted that $\log K_{120}=8.91$ almost equals $\log K_{110}=9.03$, which would suggest a cooperative uptake of the second monohydroxamato ligand, a quite unlikely situation for this class of ligands $[55,56]$. Indeed, the lower probability for the second compared to the first entering bidentate chelator to find an unoccupied binding position in the equatorial plane of a pentacoordinated 
uranium center decreases $K_{120}$ with respect to $K_{110}$. Based on that sole statistical effect, both constants should be in the $1 / 5$ ratio, translating into a $\Delta_{1,2}$ difference $\left(\Delta_{1,2}=\log K_{110}-\log K_{120}\right)$ of 0.70 units or $\Delta \Delta G_{\text {stat }}=4.0 \mathrm{~kJ} \mathrm{~mol}^{-1}$ [17]. In addition, the lower electrostatic interaction energy resulting from the overall charge reduction on the metal center upon progressive uptake of anionic ligands should further lower the binding affinity for the second hydroxamato anion and thus $\Delta_{1,2}$ values even larger than 0.70 are anticipated [17]. Based on that reasoning, the results of Dutt and Seshari [50] but also those of Glorius et al. obtained by TRLSF [48] can be considered as suspicious. The spectrophotometric measurements undertaken by the same authors [47] returned apparently more reasonable binding constants, although $K_{110}$ and $K_{120}$ are ca. 0.5 and $0.3 \log$ units higher than our values, respectively. Nevertheless, charge reduction occurs upon successive chelation of $\mathrm{UO}_{2}{ }^{2+}$ by $\mathrm{BHA}^{-}$. Thus, stability constants at infinite dilution $\left(K^{0}{ }_{110}\right)$ are predicted to be higher than those determined at the ionic strength conditions listed in Table 1. Extrapolation of $K_{1 l 0}$ values to $I=0$ can be achieved in first approximation by applying the Davies equation (Eq. (5) with $\Delta z^{2}=-4$ and -2 for $l=1$ and 2, respectively) for estimating the activity coefficients of the charged species [57]. By doing so, Glorius et al. seemingly calculated $K^{0}{ }_{1 l 0}$ values lower than those measured at $I=0.1 \mathrm{M}$ both by absorption and emission spectrophotometry [47]. If it is assumed that this obvious inconsistency is due to the accidental reversing of $K_{110}$ and $K^{0}{ }_{10}$ by the authors in both of their publications, then a good agreement can be found for their values determined by spectrophotometry [47] with those reported herein or in references [51-53].

$$
\log K_{1 l 0}^{0}=\log K_{1 l 0}-0.509 \Delta z^{2}\left(\frac{\sqrt{I}}{1+\sqrt{I}}-0.3 I\right)
$$

The binding affinity of $\mathrm{BHA}^{-}$for $\mathrm{UO}_{2}{ }^{2+}$ found herein is significantly lower than that reported at the same temperature and ionic strength for acetohydroxamate $\left(\mathrm{AHA}^{-}, \log K_{110}=8.22\right.$, $\left.\log K_{120}=7.08\right)$ [58], in agreement with the higher basicity of the latter ligand $\left(\log K_{011}=\right.$ 9.30(4) $[56,58] v s .8 .80$ at $I=0.1 \mathrm{M}$ ). In turn, the secondary hydroxamate $\mathrm{NMA}^{-}$possesses a markedly lower basicity $\left(\log K_{011}=8.68(3), I=0.1 \mathrm{M}, T=298.2 \mathrm{~K}[17]\right)$ than $\mathrm{AHA}^{-}$, owing to the stabilization of the positive charge appearing on the nitrogen atom in the iminium canonical form, but is only very slightly more acidic (by ca. $0.1 \log$ unit) than $\mathrm{BHA}^{-}$. Nevertheless, $\mathrm{NMA}^{-}$ forms a moderately stronger 1:1 complex with uranyl $\left(\log K_{110}=7.76(1)\right)$ than $\mathrm{BHA}^{-}$under similar conditions, while the reverse situation was found in the case of the $1: 2$ species $\left(\log K_{120}\right.$ $=6.14(1)$ for $\left.\mathrm{NMA}^{-}\right)$[17]. Very recently, we have investigated the speciation of the $\mathrm{UO}_{2}{ }^{2+}$ in 
the presence of the six-membered cyclic hydroxamate $\mathrm{PIPO}^{-}$by combining potentiometric, UV-vis, ACE, and Raman equilibrium measurements [17]. This chelator assumes by construction a blocked cis orientation of both donor atoms, unlike the open-chain hydroxamates, which are prone to occur in solution as a mixture of both cis and trans rotamers (Fig. 1) $[15,59,60]$. The $c i s$ conformation of $\mathrm{PIPO}^{-}$confers a higher basicity $\left(\log K_{011}=8.85(2)\right)$ and affinity towards $\mathrm{UO}_{2}{ }^{2+}\left(\log K_{110}=8.58(1), \log K_{120}=6.92(1), I=0.1 \mathrm{M}, T=298.2 \mathrm{~K}\right)$ as compared to $\mathrm{NMA}^{-}$, the stability gain amounting $0.8 \log$ units or $4.6 \mathrm{~kJ} \mathrm{~mol}^{-1}$ per bound ligand. Interestingly, $\mathrm{BHA}^{-}$, which exhibits acid-base properties very similar to those of $\mathrm{PIPO}^{-}$and which prevails in water in its $c i s$ form [59], forms significantly weaker ML ( $\log K_{110}=7.44(4)$ vs. 8.58(1)) and $\mathrm{ML}_{2}\left(\log K_{120}=6.72(5)\right.$ vs. 6.92(1)) complexes with uranyl, highlighting the advantage of a sterically constrained and predisposed structure over an acyclic one. A better solvation by the water molecules of the aliphatic $\mathrm{PIPO}^{-}$complexes might also contribute to enhance their stability.

\section{Conclusions}

This study has focused on BHAH, a hydroxamic acid carrying an aromatic carbonyl substituent. Whereas this structural feature has virtually no influence on the $\mathrm{p} K_{a}$ of $\mathrm{BHAH}$ by comparison with aliphatic analogues (NMAH and PIPOH), the binding properties of $\mathrm{BHA}^{-}$towards the uranyl dication are affected to a significant extent, since they can be viewed as intermediate between those of $\mathrm{NMA}^{-}$and $\mathrm{PIPO}^{-}$. The affinity of $\mathrm{UO}_{2}{ }^{2+}$ for a first $\mathrm{BHA}^{-}$ligand is very similar to that for $\mathrm{NMA}^{-}$, whereas the second $\mathrm{BHA}^{-}$chelate is captured with the same affinity as PIPO${ }^{-}$ . Overall, however, $\mathrm{BHA}^{-}$behaves as a standard hydroxamate as far as the complexation of $\mathrm{UO}_{2}{ }^{2+}$ in aqueous solution is concerned. The situation is more contrasted in the gas phase. The collision-induced $\mathrm{U}=\mathrm{O}$ bond cleavage phenomenon observed in the case of the $\left[\mathrm{UO}_{2}(\mathrm{NMA})(\mathrm{NMAH})_{2}\right]^{+}$species, and reported in an earlier work, could be duplicated with the PIPOH ligand, but not with BHAH. In the latter case, the more classical release of a $\mathrm{BHA}^{-}$ chelate was observed instead. Whereas gas phase studies are a direct entry into bond energetics, fundamental solution studies allow us to understand and describe phenomena taking place not only in vitro, but also in vivo. The demonstration that $\mathrm{BHA}^{-}$can complex uranyl as efficiently as aliphatic hydroxamic siderophores makes this chelate a pertinent model of humic substances, 
which have been recognized as a class of natural compounds involved in the mobilization of hard Lewis acids such as $\mathrm{UO}_{2}{ }^{2+}$ or $\mathrm{Fe}^{3+}$.

\section{Acknowledgements}

The Centre National de la Recherche Scientifique (CNRS), the Conseil Régional de Bourgogne (CRB, program PARI II CDEA), the European Regional Development Fund (FEDER), the program "Défi NEEDS Environnement" (project PiRATE), and the Agence Nationale de la Recherche (ANR project PLUTON, grant $\mathrm{N}^{\circ}$ ANR-17-CE08-0053) are gratefully acknowledged for their financial support. M.H. and P.J. thank the Chinese government and the $\mathrm{CRB}$, respectively, for their $\mathrm{PhD}$ fellowships.

\section{References}

1. IRSN sheet $N^{\circ} 1$ (2018) The extraction of uranium in France: Data and key figures (in French). Available at http://www.irsn.fr/FR/connaissances/Environnement/ expertiseslocales/sites-miniers-uranium/Documents/irsn_mines-uranium_extractionuranium_2017.pdf. Accessed April 2018

2. Crançon P, van der Lee J (2003) Radiochim Acta 92:673-679

3. Sherman DM, Peacock CL, Hubbard CG (2008) Geochim Cosmochim Acta 72:298-310

4. Mishra S, Maity S, Bhalke S, Pandit G, Puranik V, Kushwaha H (2012) J Radioanal Nucl Chem 294:97-102

5. Wang Z, Zachara JM, Boily J-F, Xia Y, Resch TC, Moore DA, Liu C (2011) Geochim Cosmochim Acta 75:2965-2979

6. Brainard JR, Strietelmeier BA, Smith PH, Langston-Unkefer PJ, Barr ME, Ryan RR (1992) Radiochim Acta 58-59:357-364

7. Bouby M, Billard I, MacCordick J, Rossini I (1998) Radiochim Acta 80:95-100

8. Renshaw JC, Halliday V, Robson GD, Trinci APJ, Wiebe MG, Livens FR, Collison D, Taylor RJ (2003) Appl Environ Microbiol 69:3600-3606

9. Ruggiero CE, Boukhalfa H, Forsythe JH, Lack JG, Hersman LE, Neu MP (2005) Environ Microbiol 7:88-97

10. Frazier SW, Kretzschmar R, Kraemer SM (2005) Environ Sci Technol 39:5709-5715

11. Wolff-Boenisch D, Traina SJ (2007) Chem Geol 242:278-287 
12. Albrecht-Gary AM, Crumbliss AL (1998) Coordination Chemistry of Siderophores: Thermodynamics and Kinetics of Iron Chelation and Release. In: Sigel A, Sigel H (eds) Metal Ions in Biological Systems. Iron Transport and Storage in Microorganisms, Plants, and Animals, vol 35. Marcel Dekker, New York, pp 239-327

13. Stintzi A, Raymond KN (2001) Siderophore Chemistry. In: Templeton DE (ed) Molecular and Cellular Iron Transport. Marcel Dekker, New York, pp 273-319

14. Dertz EA, Raymond KN (2004) Biochemical and Physical Properties of Siderophores. In: Crosa JH, Mey AR, Payne S (eds) Iron Transport in Bacteria. ASM Press, Washington, DC, pp 5-17

15. Brandès S, Sornosa-Ten A, Rousselin Y, Lagrelette M, Stern C, Moncomble A, Cornard JP, Meyer M (2015) J Inorg Biochem 151:164-175

16. Jewula P, Berthet J-C, Chambron J-C, Rousselin Y, Thuéry P, Meyer M (2015) Eur J Inorg Chem:1529-1541

17. Sornosa-Ten A, Jewula P, Fodor T, Brandes S, Sladkov V, Rousselin Y, Stern C, Chambron J-C, Meyer M (2018) New J Chem 42:7765-7779

18. Liu X, Millero FJ (2002) Mar Chem 77:43-54

19. Hiemstra T, van Riemsdijk WH (2006) Mar Chem 102:181-197

20. Frimmel FH, Geywitz J (1983) Fresenius' Z Anal Chem 316:582

21. Orlowska E, Roller A, Wiesinger H, Pignitter M, Jirsa F, Krachler R, Kandioller W, Keppler BK (2016) RSC Adv 6:40238-40249

22. Terencio T, Roithová J, Brandès S, Rousselin Y, Penouilh M-J, Meyer M (2018) Inorg Chem 57:1125-1135

23. Nakamoto K (1970) Infrared and Raman Spectra of Inorganic and Coordination Compounds. Wiley, New York

24. Chakraborty S, Dinda S, Bhattacharyya R, Mukherjee AK (2006) Z Kristallogr 221:606611

25. Hazra DK, Dinda S, Helliwell M, Bhattacharyya R, Mukherjee M (2009) Z Kristallogr $224: 544-550$

26. Silver MA, Dorfner WL, Cary SK, Cross JN, Lin J, Schelter EJ, Albrecht-Schmitt TE (2015) Inorg Chem 54:5280-5284

27. Weck PF, Gong C-MS, Kim E, Thuéry P, Czerwinski KR (2011) Dalton Trans 40:60076011

28. Centore R, De Tommaso G, Iuliano M, Tuzi A (2007) Acta Crystallogr, Sect C 63:m253$\mathrm{m} 255$ 
29. Van Stipdonk MJ, Michelini MdC, Plaviak A, Martin D, Gibson JK (2014) J Phys Chem A $118: 7838-7846$

30. Gong Y, Vallet V, del Carmen Michelini M, Rios D, Gibson JK (2014) J Phys Chem A $118: 325-330$

31. Gong Y, de Jong WA, Gibson JK (2015) J Am Chem Soc 137:5911-5915

32. Abergel RJ, de Jong WA, Deblonde GJP, Dau PD, Captain I, Eaton TM, Jian J, van Stipdonk MJ, Martens J, Berden G, Oomens J, Gibson JK (2017) Inorg Chem 56:1293012937

33. Szabó Z, Grenthe I (2007) Inorg Chem 46:9372-9378

34. Krylov SN (2007) Electrophoresis 28:69-88

35. Jiang C, Armstrong DW (2010) Electrophoresis 31:17-27

36. Timerbaev AR, Timerbaev RM (2013) Trends Anal Chem 51:44-50

37. Sladkov V (2016) Electrophoresis 37:2558-2566

38. Sladkov V (2010) Electrophoresis 31:3482-3491

39. Sladkov V (2013) J Chromatogr A 1276:120-125

40. Sladkov V (2014) J Chem Thermodyn 71:148-154

41. Sladkov V, Bessonov AA, Roques J, Charushnikova IA, Fedosseev AM (2018) New J Chem 42:7780-7788

42. Okhonin V, Berezovski MV, Krylov SN (2010) J Am Chem Soc 132:7062-7068

43. Kanoatov M, Cherney LT, Krylov SN (2014) Anal Chem 86:1298-1305

44. Sladkov V (2013) J Chromatogr A 1289:133-138

45. Frassineti C, Ghelli S, Gans P, Sabatini A, Moruzzi MS, Vacca A (1995) Anal Biochem $231: 374-382$

46. Topin S, Aupiais J, Baglan N, Vercouter T, Vitorge P, Moisy P (2009) Anal Chem 81:53545363

47. Glorius M, Moll H, Bernhard G (2007) Radiochim Acta 95:151-157

48. Glorius M, Moll H, Geipel G, Bernhard G (2008) J Radioanal Nucl Chem 277:371-377

49. Baroncelli F, Grossi G (1965) J Inorg Nucl Chem 27:1085-1092

50. Dutt NK, Seshadri T (1969) J Inorg Nucl Chem 31:2153-2157

51. Khairy EM, Shoukry MM, Khalil MM, Mohamed MMA (1996) Transition Met Chem 21:176-180

52. Khalil MM, El-Deeb MM, Mahmoud RK (2007) J Chem Eng Data 52:1571-1579

53. Koide Y, Uchino M, Shosenji H, Yamada K (1989) Bull Chem Soc Jpn 62:3714-3715

54. Maggio F, Romano V, Cefalù R (1966) J Inorg Nucl Chem 28:1979-1984 
55. Kurzak B, Kozłowski H, Farkas E (1992) Coord Chem Rev 114:169-200

56. Farkas E, Kozma E, Petho M, Herlihy KM, Micera G (1998) Polyhedron 17:3331-3342

57. Grenthe I, Wanner H, Östhols E (2000) TDB-2 Guidelines for the extrapolation to zero ionic strength. OECD Nuclear Energy Agency, Issy-les-Moulineaux

58. Martell AE, Smith RM, Motekaitis RJ (2004) NIST Critically Selected Stability Constants of Metal Complexes Database. 8.0 edn. NIST Standard Reference Database No. 46, Gaithersburg, MD

59. García B, Ibeas S, Leal JM, Secco F, Venturini M, Senent ML, Niño A, Muñoz C (2005) Inorg Chem 44:2908-2919

60. Sippl SP, Schenck HL (2013) Magn Reson Chem 51:72-75 